\title{
Development of EST-SSR and genomic-SSR markers to assess genetic diversity in Jatropha Curcas L
}

\author{
Mingfu Wen ${ }^{1,2}$, Haiyan Wang ${ }^{1}$, Zhiqiang Xia ${ }^{1}$, Meiling Zou', Cheng Lu', Wenquan Wang ${ }^{1 *}$
}

\begin{abstract}
Background: Jatropha curcas $L$. has attracted a great deal of attention worldwide, regarding its potential as a new biodiesel crop. However, the understanding of this crop remains very limited and little genomic research has been done. We used simple sequence repeat (SSR) markers that could be transferred from Manihot esculenta (cassava) to analyze the genetic relationships among 45 accessions of J. curcas from our germplasm collection.

Results: In total, 187 out of 419 expressed sequence tag (EST)-SSR and 54 out of 182 genomic (G)-SSR markers from cassava were polymorphic among the J. curcas accessions. The EST-SSR markers comprised $26.20 \%$ dinucleotide repeats, $57.75 \%$ trinucleotide repeats, $7.49 \%$ tetranucleotide repeats, and $8.56 \%$ pentanucleotide repeats, whereas the majority of the G-SSR markers were dinucleotide repeats (62.96\%). The 187 EST-SSRs resided in genes that are involved mainly in biological and metabolic processes. Thirty-six EST-SSRs and 20 G-SSRs were chosen to analyze the genetic diversity among $45 \mathrm{~J}$. curcas accessions. A total of 183 polymorphic alleles were detected. On the basis of the distribution of these polymorphic alleles, the 45 accessions were classified into six groups, in which the genotype showed a correlation with geographic origin. The estimated mean genetic diversity index was 0.5572 , which suggests that our J. curcas germplasm collection has a high level of genetic diversity. This should facilitate subsequent studies on genetic mapping and molecular breeding.

Conclusion: We identified 241 novel EST-SSR and G-SSR markers in J. curcas, which should be useful for genetic mapping and quantitative trait loci analysis of important agronomic traits. By using these markers, we found that the intergroup gene diversity of J. curcas was greater than the intragroup diversity, and that the domestication of the species probably occurred partly in America and partly in Hainan, China.
\end{abstract}

\section{Background}

Jatropha curcas $L$. is a perennial, monoecious shrub that belongs to the Euphorbiaceae family. The species is native to America but is distributed widely in the tropics $[1,2]$. Wild or semicultivated types of $J$. curcas can grow well under all unfavorable climatic and soil conditions [3]. The seeds of J. curcas contain 40-45\% oil [4-6] with a high percentage of monounsaturated oleic and polyunsaturated linoleic acid. The seed oils can be classified as semi-drying [7]. In recent years, the economic importance of $J$. curcas for the production of biodiesel fuel has been increasingly recognized [8].

\footnotetext{
* Correspondence: wquanw@hainan.net

${ }^{1}$ Institute of Tropical Biosciences \& Biotechnology, Chinese Academy of Tropical Agricultural Science, 571101, Haikou, Hainan, PR China
}

To use J. curcas for producing biofuel, it is crucial to develop varieties with a high seed yield and a high oil content that are adapted well to varied conditions [9]. In recent years, J. curcas germplasm has been collected and analyzed in Brazil, India, Indonesia, and China $[10,11]$. J. curcas has a heterozygous genome, so conventional breeding programs for its improvement might not be effective. Hence, it is likely that genomics-based breeding strategies need to be used. However, the genetic map of $J$. curcas is not well-developed and very limited information is available with respect to molecular markers. The traditional methods of developing simple sequence repeat (SSR) markers are usually timeconsuming and labor-intensive. However, an alternative strategy has been developed that uses comparative

C Biomed Central

(c) 2010 Wang et al; licensee BioMed Central Ltd. This is an Open Access article distributed under the terms of the Creative Commons Attribution License (http://creativecommons.org/licenses/by/2.0), which permits unrestricted use, distribution, and reproduction in any medium, provided the original work is properly cited. 
genomics to identify SSR markers. This strategy has been used successfully in barley [12] and Brassica [13].

In the study reported herein, we selected 419 expressed sequence tag (EST)-SSR and 182 genomic (G)-SSR primer pairs that had been developed for Manihot esculenta (cassava), which also belongs to the Euphorbiaceae family, and investigated whether they could be transferred to J. curcas. Firstly, these primer pairs were tested using five accessions of $J$. curcas. The primer pairs that produced specific amplicons were then tested further. Finally, we used the transferable markers to analyze the genetic diversity of our collection of J. curcas accessions.

\section{Results}

Identification of EST-SSRs and G-SSRs for use in J. curcas Five accessions of $J$. curcas were used to test the transferability of 419 EST-SSR and 182 G-SSR primer pairs between cassava and J. curcus. Among these primers, 234 (55.85\%) EST-SSR and 68 (37.36\%) G-SSR primer pairs produced amplicons, but only 187 (44.63\%) ESTSSRs and 54 (29.67\%) G-SSRs were polymorphic among the five accessions (Fig.1). For each of the 241 EST-SSR and G-SSR markers in J. curcas, the name, sequence of the forward and reverse primers, the repeat type, annealing temperature, and expected size of the PCR products are listed in additional file 1.

\section{Characteristics of the EST-SSR and G-SSR markers and relevant genes in $J$. curcas}

Microsatellites or SSRs are regions in the genome of tandemly repeated DNA segments, with each segment comprising up to six bases. Analysis of the nucleotide sequences of the EST- and G-SSRs showed that, in J. curcas, the EST-SSRs corresponded to $57.75 \%$ trinucleotide repeats, $26.20 \%$ dinucleotide repeats, $8.56 \%$ pentanucleotide repeats, and $7.49 \%$ tetranucleotide repeats. In contrast, the G-SSRs were composed mainly of dinucleotide repeats $(62.96 \%)$ (Table 1$)$.

A BLAST search of the GenBank database was performed using the sequences of the 187 EST-SSRs. The functions of the ESTs were then clustered according to
Table 1 Structural characteristics of the ES T-SSR and G-SSR markers in J. curcas

\begin{tabular}{cccccccc}
\hline Repeat type & \multicolumn{3}{c}{ EST-SSR } & \multicolumn{3}{c}{ G-SSR } \\
\cline { 2 - 4 } & No. & \multicolumn{2}{c}{ Polymorphic } & No. & \multicolumn{2}{c}{ Polymorphic } \\
\cline { 3 - 4 } \cline { 3 - 5 } & & \multicolumn{2}{c}{$\begin{array}{c}\text { Number and } \\
\text { percentage }\end{array}$} & & $\begin{array}{c}\text { Number and } \\
\text { percentage }\end{array}$ \\
\hline Di & 57 & 49 & 26.20 & 43 & 34 & 62.96 \\
Tri & 139 & 108 & 57.75 & 4 & 2 & 3.70 \\
Tetra & 20 & 16 & 8.56 & - & - & - \\
Penta & 18 & 14 & 7.49 & - & - & - \\
Total & 234 & 187 & 100 & 68 & 54 & 100 \\
\hline
\end{tabular}

the general functional categories in the KOG (Eukaryotic Orthologous Groups of Proteins) database. A general functional classification of the EST-SSRs is shown in Fig. 2. Out of the 187 unique ESTs, 184 were annotated and they were classified into more than 55 categories. Many ESTs were found in several categories. The five main categories, which contained 137 of the ESTs, were biological processes, cellular processes, metabolic processes, cellular metabolic processes, and primary metabolic processes.

\section{Assessment of genetic diversity in J. curcas}

Thirty-six EST-SSRs and 20 G-SSRs were used to estimate the genetic diversity of 45 accessions of $J$. curcas. A total of 216 alleles were identified, and 183 (84.72\%) of them were polymorphic. The sizes of the amplicons for the EST-SSRs and G-SSRs ranged from 120 to 600 bp. The 36 EST-SSRs generated 152 alleles, of which $128(84 \%)$ were polymorphic, whereas the 20 G-SSRs produced 64 alleles, of which 55 (86\%) were polymorphic. The number of alleles for each G-SSR ranged from one to six with a mean of 3.20; in contrast, the number of alleles for each EST-SSR ranged from one to nine with a mean of 4.22 . Therefore, more alleles were obtained with the EST-SSRs than with the G-SSRs.

Genotyping data that were obtained for all 183 polymorphic alleles were used to estimate pairwise similarity comparisons among these accessions. The similarity coefficient values of the phenogram ranged from 0.55 to

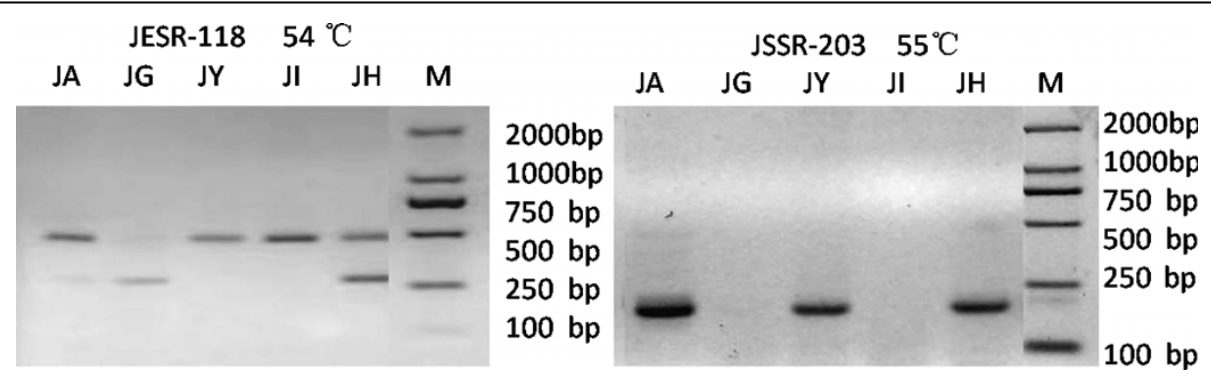

Figure 1 PCR amplification of the loci JESR-118 (CESR0806) and JSSR-203 (SSRY100) in five accessions of Jatropha curcas 


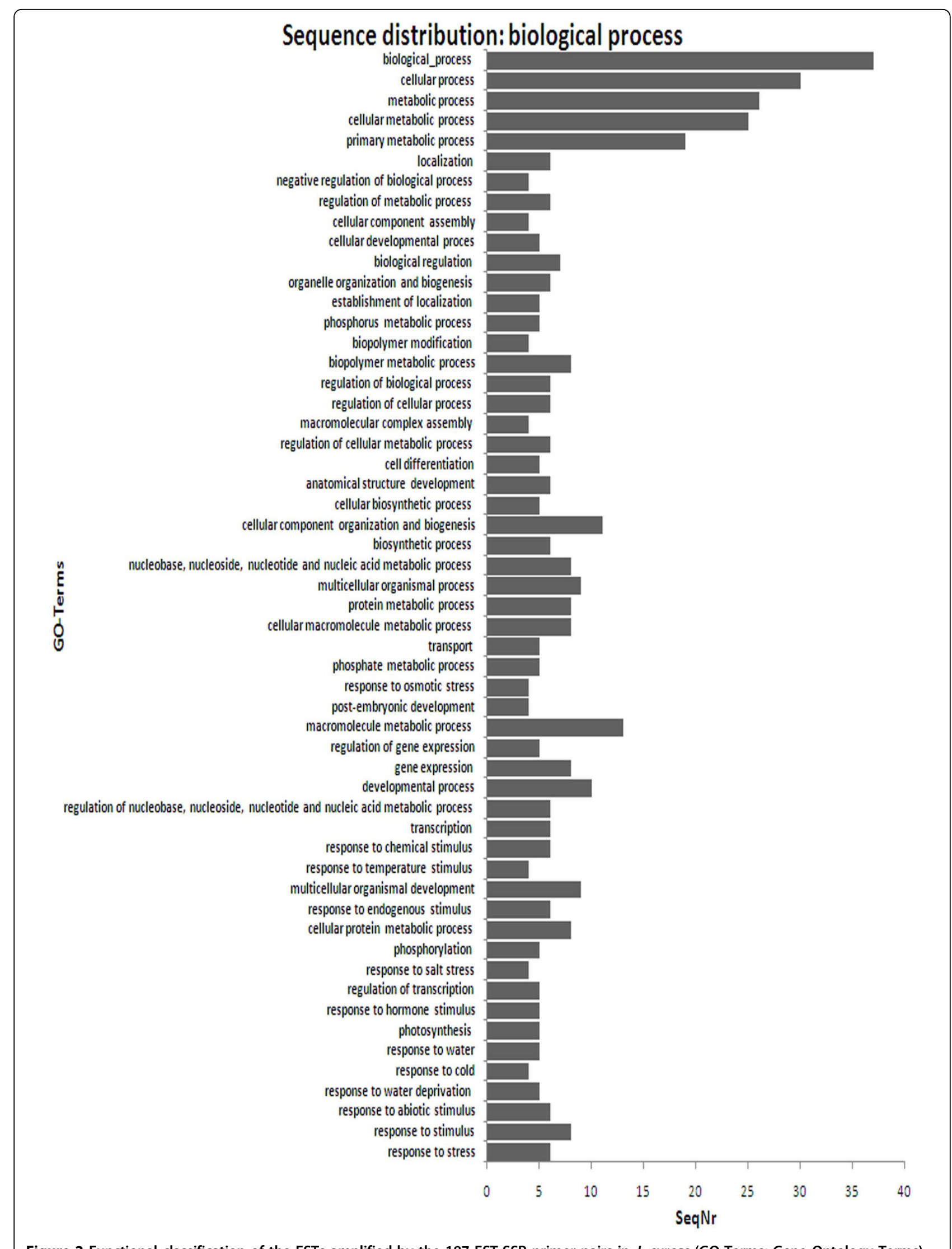

Figure 2 Functional classification of the ESTs amplified by the 187 EST-SSR primer pairs in J. curcas (GO-Terms: Gene Ontology Terms). 


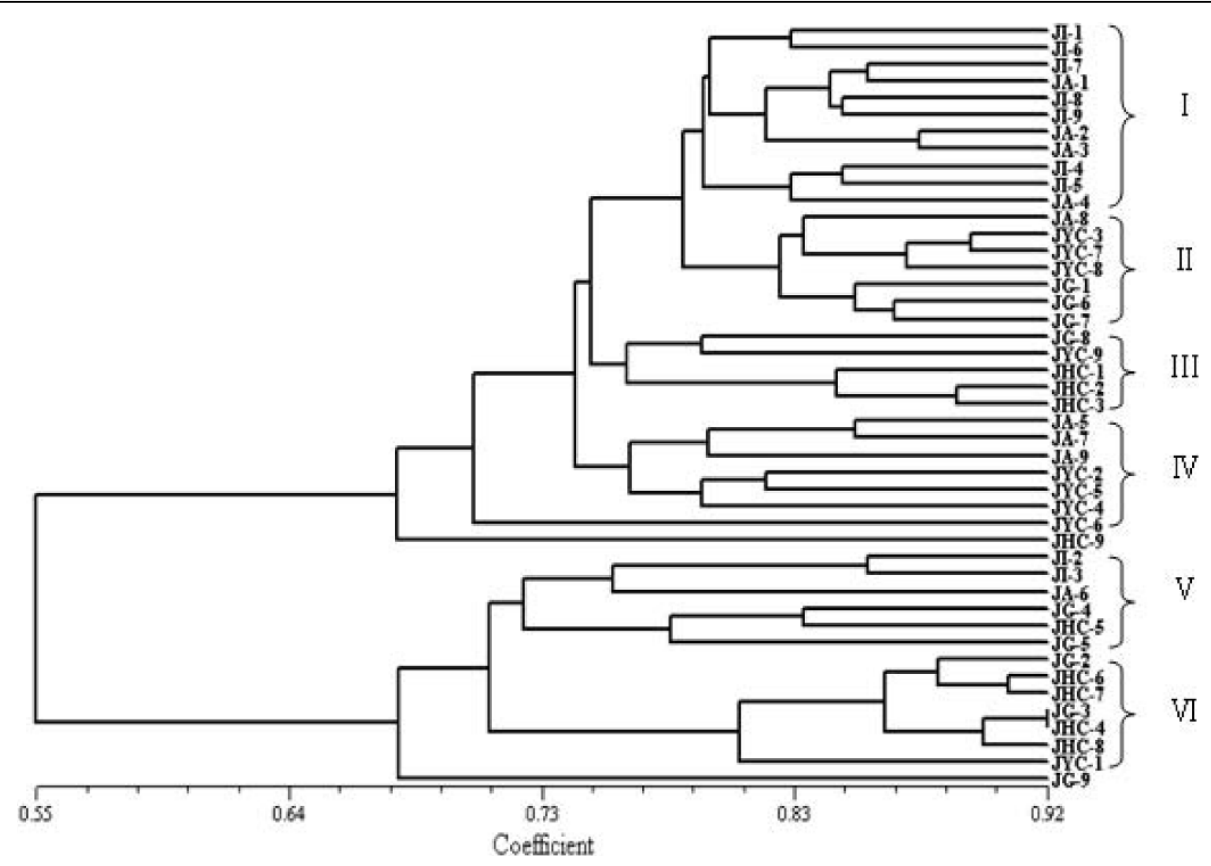

Figure 3 An UPGMA tree of the 45 Jatropha accessions

0.92 with a mean of 0.76 (Fig. 3). The 45 accessions clustered into six groups: group I, which comprised seven accessions from Indonesia and four from South America; group II, which comprised three accessions from Grenada, one from South America, and three from Yunnan, China; Group III, in which all four accessions were from Hainan, China; Group IV, which comprised four accessions from Yunnan, China plus three American clones; Group V, which consisted of two accessions from Indonesia, two from Grenada, one from America, and one from Hainan, China; and Group VI, which comprised four clones from Hainan, China, three from Grenada, and one from Yunnan, China. The results suggested that, in general, the genotypes of the J. curcas accessions are correlated with their geographic origins, although some crosses had occurred.

The parameters of genetic diversity between and within the five geographic groups (Table 2) were estimated using all 183 EST-SSR and G-SSR polymorphic alleles. The genetic diversity index ranged from 0.4099 to 0.5022 with an average of 0.5572 , which suggested that the collection had a broad genetic background, although the level of genetic diversity was higher among the accessions from America and Yunnan, China. The total gene diversity $(\mathrm{Ht}=0.3819 \pm 0.0197)$ was higher than the gene diversity within groups $(\mathrm{Hs}=0.3108 \pm$ $0.0158)$, which indicated that the genetic diversity between groups is greater than that within groups. The
Table 2 Parameters of intra- and intergroup genetic diversity among the five populations of $J$. curcas

\begin{tabular}{lccccccc}
\hline Population & $\mathbf{n}$ & \#loc_P & $\begin{array}{c}\text { PLP } \\
(\mathbf{\%})\end{array}$ & na & ne & H & I \\
\hline Indonesia & 9 & 118 & 54.63 & 1.7541 & 1.5769 & 0.3140 & 0.4526 \\
Grenada & 9 & 100 & 46.30 & 1.6995 & 1.5046 & 0.2818 & 0.4099 \\
South & 9 & 147 & 68.06 & 1.8907 & 1.5763 & 0.3326 & 0.4920 \\
America & & & & & & & \\
Yunnan, & 9 & 108 & 50.00 & 1.8361 & 1.6274 & 0.3473 & 0.5022 \\
China & & & & & & & \\
Hainan, & 9 & 148 & 68.52 & 1.8142 & 1.4575 & 0.2785 & 0.4221 \\
China & & & & & & & \\
Total & 45 & 183 & 84.72 & 2.0000 & 1.6869 & 0.3819 & 0.5572 \\
St. Dev & - & - & - & \pm & \pm & \pm & \pm \\
& & & & 0.0000 & 0.3107 & 0.1403 & 0.1741 \\
\hline & & & & Ht & Hs & Gst & Nm \\
\hline Mean & & & & 0.3819 & 0.3108 & 0.1861 & 2.1868 \\
St. Dev & & & & \pm & \pm & & \\
& & & & 0.0197 & 0.0158 & & \\
\hline
\end{tabular}

$\mathrm{n}$ = number of genotypes per sample;

\#loc $\mathrm{P}=$ number of polymorphic loci;

PLP = percentage of polymorphic loci;

na = observed number of alleles;

ne $=$ effective number of alleles [Kimura and Crow (1964)];

h = Nei's (1973) gene diversity;

I = average genetic diversity index;

$\mathrm{Ht}=$ total gene diversity;

$\mathrm{Hs}=$ intrapopulation gene diversity;

Gst = coefficient of gene differentiation;

$\mathrm{Nm}=$ estimate of gene flow from Gst; $\mathrm{Nm}=0.5$ (1-Gst)/Gst 
coefficient of gene differentiation (Gst) was 0.1861 , which indicated that the level of genetic differentiation among the five groups was relatively high. The gene flow index $(\mathrm{Nm})$ was 2.18 , which indicated that high levels of gene flow occurred during the domestication of J. curas.

The genetic similarity matrix that was obtained from Jaccard's similarity coefficient was subjected to principal coordinates analysis (PCA). The results indicated that all 45 accessions could be divided into three categories (Fig. 4). Category I contained the most accessions and they came from all five areas. Category II included eight accessions in total: three from Grenada, two from Indonesia, two from Hainan, and one from America. Category III contained four accessions from Hainan, two from Grenada, and one from Yunnan. Category I included many accessions from different areas, and therefore demonstrated the weak geographic differentiation in the population; in other words, the observed genetic diversity was due mainly to original evolution. The category II and category III clusters revealed that the phylogenetic characteristics of J. curcas from South America, where J. curcas originated, and from Hainan in China, where the species was domesticated less than 300 years ago, were very similar.

\section{Discussion}

\section{Development of molecular markers in J. curcas}

It was crucial to develop a sufficient number of speciesspecific markers to enable the fingerprinting and genetic mapping of J. curcas; in rice and soybean, for example, more than 10,000 SSR and SNP markers are available $[14,15]$. Random amplified polymorphic DNA (RAPD), inter-simple sequence repeat (ISSR) and amplified fragment length polymorphism (AFLP) markers have been used to evaluate genetic diversity and for fingerprinting in accessions of $J$. curcas and related species [11,16-18]. Up to now, only 12 SSR markers had been developed for Jatropha (they are polymorphic in six species of Jatropha) [19], and no genetic map of Jatropha has been reported. The transferable SSRs identified in the present study should enable the genetic diversity, elite clones, and evolution of $J$. curcas to be assessed, and a linkage map to be constructed.

\section{Transferability of EST-SSRs and G-SSRs from cassava}

The development of EST-SSR markers was particularly attractive because they represent coding regions of the genome. It has been reported that EST-derived SSRs and G-SSRs show a considerable degree of transferability to related species [20-24]. In the present study, we observed a high level of transferability from cassava to J. curcas; the level of transferability was higher for ESTSSRs (44.63\%) than for G-SSRs (29.67\%). This result was consistent with that reported for wheat and related species [25]. In several studies, the level of transferability of G-SSRs was found to be only 20-30\% [26-29]. The higher levels of transferability of EST-SSRs than of G-SSRs reflect the conserved nature of coding sequences as compared with non-coding genomic DNA, and the

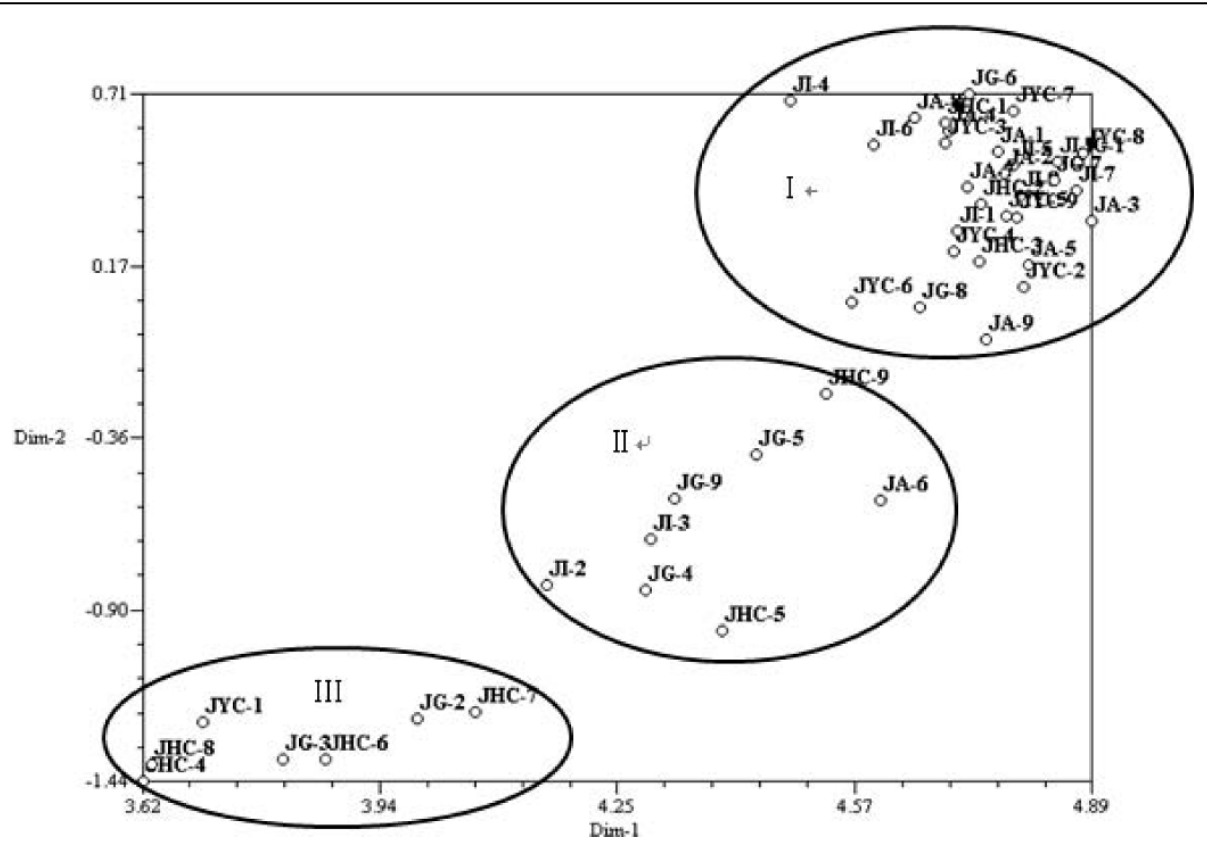

Figure 4 Two-dimensional PCA plot of the $45 \mathrm{~J}$. curcas accessions. 
fact that the mutation frequency of EST sequences is lower than that of genomic DNA sequences. These results demonstrate the potential value of EST-SSR markers for the development of genetic maps, assessment of genetic diversity, and marker-assisted selection (MAS) breeding in J. curcas, all of which would benefit comparative mapping and analysis of the comparative functions of genes among the economic species in the Euphorbiaceae family. Our finding that the majority of transferable EST-SSRs were trinucleotide repeats agreed with previous studies [21,30-32], and can be explained by the suppression of non-trimeric SSRs in coding regions due to the risk of frameshift mutations, which might occur with non-trimeric microsatellites [33-36].

\section{Collection of germplasm and evaluation of genetic diversity}

Several projects to collect germplasm have been carried out in Brazil [37], India [38], and China [39], but systematic work on the collection of germplasm and its evaluation is still in its infancy. The low genetic variability found among accessions of $J$. curcas from Africa and Asia $[11,16,17]$ has demonstrated the need for new sources of genetic variation in $J$. curcas that could be used in breeding programs. Such sources of genetic variation have been identified in Latin America, especially in Guatemala [40]. In the present study, high levels of genetic diversity were revealed in the 45 Jatropha accessions analyzed with the 56 EST-SSR and G-SSR primer pairs that were utilized. The accessions from South America, Yunnan (China), and Indonesia showed higher levels of genetic variation than the other two geographic regions (Grenada and Hainan, China). In particular, the collections from Yunnan (China) could be used to enrich the genetic background of $J$. curcas for breeding.
Gst and Nm showed that some differentiation occurred in each geographic group.

\section{Conclusion}

We developed a set of 241 SSR primer pairs for use in J. curcas. Of these markers, 187 EST-SSRs should be useful for genetic mapping and quantitative trait loci analysis of important agronomic traits. Fifty-six EST-SSRs and G-SSRs were used successfully to analyze genetic diversity in 45 accessions of $J$. curcas. The accessions analyzed showed a broad genetic background with an average genetic diversity index of 0.5572 . The intergroup genetic diversity was larger than the intragroup diversity, and domestication had taken place in both America and Hainan, China.

\section{Methods}

Plant material

Five $J$. curcas accessions, which corresponded to JI-1 (Indonesia), JA-1(America), JG-1 (Grenada), JYC-1(Yunnan, China), and JHC-1(Hainan, China), were used to test the suitability of the cassava SSR markers by PCR. To analyze the genetic diversity of J. curcas, 45 accessions were chosen, nine from each of the five above-mentioned regions (Table 3 ). All the materials were obtained from the germplasm collection of the Institute of Tropical Biosciences \& Biotechnology, Chinese Academy of Tropical Agricultural Sciences, Haikou, China. This collection contains 154 J. curcas accessions, which cover most of the Chinese collections as well as accessions from eight other countries: Brazil, Columbia, Grenada, Thailand, Indonesia, Laos, Myanmar, and Nigeria. Total genomic DNA was isolated from young leaves by the modified CTAB method as described by Doyle and Doyle [41]. The genomic DNA

Table 3 The J. curcas accessions and their origins

\begin{tabular}{|c|c|c|c|c|c|}
\hline Code & District of collection & Code & District of collection & Code & District of collection \\
\hline J-1 & Indonesia & $J A-7$ & South America & $J Y C-4$ & Yunnan, China \\
\hline J-2 & Indonesia & JA-8 & South America & JYC-5 & Yunnan, China \\
\hline J-3 & Indonesia & JA-9 & South America & JYC-6 & Yunnan, China \\
\hline J-4 & Indonesia & $J G-1$ & Grenada & JYC-7 & Yunnan, China \\
\hline J-5 & Indonesia & $J G-2$ & Grenada & JYC-8 & Yunnan, China \\
\hline 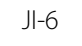 & Indonesia & $J G-3$ & Grenada & JYC-9 & Yunnan, China \\
\hline J-7 & Indonesia & $J G-4$ & Grenada & $J H C-1$ & Hainan, China \\
\hline J-8 & Indonesia & $J G-5$ & Grenada & $\mathrm{JHC}-2$ & Hainan, China \\
\hline J-9 & Indonesia & $J G-6$ & Grenada & $J H C-3$ & Hainan, China \\
\hline JA-1 & South America & $J G-7$ & Grenada & $J H C-4$ & Hainan, China \\
\hline $\mathrm{JA}-2$ & South America & $J G-8$ & Grenada & $J H C-5$ & Hainan, China \\
\hline $\mathrm{JA}-3$ & South America & $J G-9$ & Grenada & $J H C-6$ & Hainan, China \\
\hline $\mathrm{JA}-4$ & South America & JYC-1 & Yunnan, China & $J H C-7$ & Hainan, China \\
\hline JA-5 & South America & JYC-2 & Yunnan, China & $J H C-8$ & Hainan, China \\
\hline JA-6 & South America & JYC-3 & Yunnan, China & $J H C-9$ & Hainan, China \\
\hline
\end{tabular}


was diluted to a concentration of $25 \mathrm{ng} / \mu \mathrm{l}$ for PCR amplification.

\section{Design of EST-SSR and G-SSR primers and validation in J. curcas}

A total of 419 EST-SSR primers that had been developed for cassava in our laboratory [42] and 182 G-SSR primers [43] were synthesized and used. Amplification by PCR was performed in a $20-\mu \mathrm{l}$ reaction mixture that contained $50 \mathrm{ng}$ template DNA, $1 \times$ PCR buffer $(20 \mathrm{mM}$ Tris pH 9.0, $\left.100 \mathrm{mM} \mathrm{KCl}, 3.0 \mathrm{mM} \mathrm{MgCl}_{2}\right), 400 \mu \mathrm{M}$ of each of the four dNTPs, $0.4 \mu \mathrm{M}$ of each of the forward and reverse primers, and one unit of Taq DNA polymerase. The following PCR conditions were used: $94^{\circ} \mathrm{C}$ for $1 \mathrm{~min}$, followed by 35 cycles of $94^{\circ} \mathrm{C}$ for $1 \mathrm{~min}, 45$ $57^{\circ} \mathrm{C}$ for $1 \mathrm{~min}, 72^{\circ} \mathrm{C}$ for $1 \mathrm{~min}$, and $10 \mathrm{~min}$ at $72^{\circ} \mathrm{C}$ for the final extension. PCR products were separated on a $2 \%$ agarose gel, and visualized using SYBR Green http:// www.Genecopoeia.com.

\section{Putative functional annotation of EST-SSRs}

To assess the putative function of the EST-SSRs developed here, a BLASTX search of the GenBank nonredundant database http://www.ncbi.nlm.nih.gov/BLAST was performed using the 187 ESTs that contained polymorphic microsatellites. The threshold for a significant BLAST hit was set at a bit score greater than 80 bits. Functional categories were assigned on the basis of the BLAST searches using a specially formatted database of the Eukaryotic Orthologous Groups of proteins (KOG).

\section{Analysis of genetic diversity}

The polymorphic alleles obtained with each primer pair were scored for their presence (1) or absence (0). From the data matrix, a dendrogram was constructed using the unweighted pair group method using arithmetic averages (UPGMA), the similarity coefficient, and the software NTSYS-pc2.1 [44]. The binary data were also subjected to PCA to investigate the structure of our collection. The genetic diversity parameters of each geographic group, which included the percentage of polymorphic loci (PLP), observed number of alleles per locus (na), effective number of alleles per locus (ne), Nei's gene diversity (h), Shannon's information index (I), Gst, and Nm, were calculated by POPGENE 32 [45].

Additional file 1: The EST-SSR and G-SSR markers in Jatropha curcas. the name, sequence of the forward and reverse primers, the repeat type, annealing temperature, and expected size of the PCR products are listed in Additional file 1.

Click here for file

[ http://www.biomedcentral.com/content/supplementary/1756-0500-3-42S1.DOC ]

\section{Acknowledgements}

This work was supported by the Cooperative Research Foundation of China and Brazil (2008KR0395) and the Basic Scientific Research Foundation of the Institute of Tropical Bioscience and Biotechnology, Chinese Academy of Tropical Agricultural Science (ITBBZX0843). The authors wish to thank M Fregene of the International Center for Tropical Agriculture (CIAT) for assistance with the development of the cassava G-SSR primers and Ruqiang $\mathrm{Xu}$ of the Virginia Commonwealth University for excellent suggestions and discussions about the paper. Finally, the authors wish to thank Cathel Kerr, Lucy Colegrove, and Chris Wright of Genedits http://www.genedits.com for editing.

\section{Author details}

${ }^{1}$ Institute of Tropical Biosciences \& Biotechnology, Chinese Academy of Tropical Agricultural Science, 571101, Haikou, Hainan, PR China. ${ }^{2}$ College of Agronomy, Hainan University, 571737, Danzhou, Hainan, PR China.

\section{Authors' contributions}

MW and HW contributed to the design of the study, performed the polymorphic amplification of the EST-SSR primers in J. curcas, and prepared the manuscript. ZX contributed to the analysis of the data. MZ identified the EST-SSR primers in cassava. CL participated in the collection of the germplasm. WW was responsible for the research and the manuscript. All authors read and approved the final manuscript.

\section{Competing interests}

The authors declare that they have no competing interests.

Received: 28 January 2010 Accepted: 24 February 2010 Published: 24 February 2010

\section{References}

1. Cano-Asseleih LM: Chemical investigation of Jatropha Curcas L. seeds. Ph. D. Thesis University of London, UK 1986.

2. Cano-Asseleih LM, Plumbly RA, Hylands PJ: Purification and partial characterization of the hemagglutination from seeds of Jatropha Curcas L.. Jour Food Biochem 1989, 13:1-20.

3. Katwal RPS, Soni PL: Biofuels: an opportunity for socioeconomic development and cleaner environment. Indian Forester 2003, 129:939-949.

4. Wink M, Koschmieder C, Sauerwein M, Sporer F: Phorbol esters of J. curcas-biological activities and potential applications. DBV Graz Biofuels and Industrial Products from Jatropha curcasGubitz GM, Mittelbach M, Trabi M 1997, 160-166

5. Makkar HPS, Becker K: Potential of J. curcas seed meal as a protein supplement to livestock feed; constraints to its utilization and possible strategies to overcome constraints. DBV Graz Biofuels and Industrial Products from V HVGiibitz GM, Mittelbach M, Trabi M 1997, 190-205.

6. Openshaw K: A review of Jatropha Curcas $L$ : an oil plant of unfulfilled promise. Biomass Bioenergy 2000, 19:1-15.

7. Akintayo ET: Characteristics and composition of Parkia biglobbossa and Jatropha Curcas L. oils and cakes. Bio-resour Technol 2004, 92:307-310.

8. Fairless D: Biofuel: The little shrub that could maybe. Nature 2007 449:652-655

9. Divakara BN, Upadhyaya HD, Wani SP, Laxmipathi Gowda CL: Biology and genetic improvement of Jatropha curcas L.: A review. Applied Energy 2010, 87:732-742.

10. Ou WJ, Wang WQ, Li KM: Molecular Genetic Diversity Analysis of 120 Accessions Jatropha curcas L. Germplasm. Chinese Journal of Tropical Crops 2009, 30:287-292.

11. Tatikonda Leela, Wani PSuhas, Kannan Seetha, et al: AFLP-based molecular characterization of an elite germplasm collection of Jatropha Curcas $L$. a biofuel plant. Plant Science 2009, 176:505-513.

12. Rajeev KV, Ralf $S$, Andreas $B$, et al: Interspecific transferability and comparative mapping of barley EST-SSR markers in wheat, rye and rice. Plant Science 2005, 168:195-202.

13. Suwabe K, Tsukazaki H, Iketani H, Hatakeyama K, Kondo M, Fujimura M, Nunome T, Fukuoka H, Hirai M, Matsumoto S. Simple Sequence Repeat- 
Based Comparative Genomics Between Brassica rapa and Arabidopsis thaliana: The Genetic Origin of Clubroot Resistance. Genetics 2006, 173:309-319.

14. Wang YH, Xue YB, Li JY: Towards molecular breeding and improvement of rice in China. TRENDS in Plant Science 2005, 10:610-614.

15. Xu YB, Susan RM, Zhang Q: How can we use genomics to improve cereals with rice as a reference genome. Plant Molecular Biology 2005, 59:7-26.

16. Basha SD, George F, Makkar HPS, Becker K, Sujatha M: A comparative study of biochemical traits and molecular markers for assessment of genetic relationships between Jatropha Curcas L. germplasm from different countries. Plant Science 2009, 176:812-823.

17. Basha SD, Sujatha M: Inter and intra-population variability of Jatropha curcas (L.) characterized by RAPD and ISSR markers and development of population-specific SCAR markers. Euphytica 2007, 156:375-386.

18. Ganesh Ram S, Parthiban KT, Senthil Kumar R, Thiruvengadam V, Paramathma M: Genetic diversity among Jatropha species as revealed by RAPD markers. Genet Resour Crop Evol 2008, 55:803-809.

19. Sudheer Pamidimarri DVN, Sweta S, Shaik GM, Jalpa P, Muppala PR: Molecular characterization and identification of markers for toxic and non-toxic varieties of Jatropha curcas L. using RAPD, AFLP and SSR markers. Molecular Biology Reports 2008, 36:1357-1364.

20. Cordeiro GM, Casu R, Mclntyre CL, Manners JM, Henry RJ: Microsatellite markers from sugarcane (Saccharum spp.) ESTs cross transferable to erianthus and sorghum. Plant Science 2001, 160:1115-1123.

21. Thiel T, Michalek W, Varshney RK, Graner A: Exploiting EST databases for the development of cDNA derived microsatellite markers in barley (Hordeum vulgare L.). Theor Appl Genet 2003, 106:411-422.

22. Gupta PK, Rustgi S, Sharma S, Singh R, Kumar N, Balyan HS: Transferable EST-SSR markers for the study of polymorphism and genetic diversity in bread wheat. Mol Gen Genomics 2003, 270:315-323.

23. Bory S, Silva DD, Risterucci AM, et al: Development of microsatellite markers in cultivated vanilla: Polymorphism and transferability to other vanilla species. Scientia Horticulturae 2008, 115:420-425.

24. Wunsch A: Cross-transferable polymorphic SSR loci in Prunus species. Scientia Horticulturae 2009, 120:348-352.

25. Zhang LY, Bernard M, Leroy $P$, et al: Hight transferability of bread wheat EST-derived SSRs to other cereals. Theor Appl Genet 2005, 111:677-687.

26. Roder MS, Korzun V, Wendehake K, Plaschke J, Tixier MH, Leroy P, Ganal MW: A microsatellite map of wheat. Genetics 1998, 149:2007-2023.

27. Varshney RK, Kumar A, Balyan HS, Roy JK, Prasad M, Gupta PK: Characterization of microsatellites and development of chromosome specific STMS markers in bread wheat. Plant Mol Biol Rep 2000, 18:1-12.

28. Sourdille P, Tavaud M, Charmet G, Bernard M: Transferability of wheat microsatellites to diploid Triticeae species carrying the A, B and D genomes. Theor Appl Genet 2001, 103:346-352.

29. Tahan $O$, Geng YP, Zeng LY, et al: Assessment of genetic diversity and population structure of Chinese wild almond, Amygdalus nana, using EST- and genomic SSRs. Biochemical Systematics and Ecology 2009, 37:146-153.

30. Li LZ, Wang JJ, Guo Y, et al: Development of SSR markers from ESTs of gramineous species and their chromosome location on wheat. Progress in Natural Science 2008, 18:1485-1490.

31. Gao LF, Tang JF, Li HW, et al: Analysis of microsatellites in major crops assessed by computational and experimental approaches. Mol Breed 2003, 12:245-261.

32. Chen HM, Li LZ, Wei XY, et al: Development, chromosome location and genetic mapping of EST-SSR markers in wheat. Chin Sci Bull 2005, 50:2328-2336

33. Metzgar D, Bytof J, Wills C: Selection against frameshift mutations limits microsatellite expansion in coding DNA. Genome Res 2000, 10:72-80.

34. Wang D, Liao XL, Cheng L, et al: Development of novel EST-SSR markers in common carp by data mining from public EST sequences. Aquaculture 2007, 271:558-574

35. Chen CX, Zhou P, Choi YA, Huang S, Gmitter FG: Mining and characterizing microsatellites from citrus ESTs. Theor Appl Genet 2006, 112:1248-1257.

36. Kantety RV, Rota ML, Matthews DE, Sorrells ME: Data mining for simple sequence repeats in expressed sequence tags from barley, maize, rice, sorghum and wheat. Plant Mol Biol 2002, 48:501-510.
37. Vieira RF: Conservation of medicinal and aromatic plants in Brazil. Perspectives on new crops and new uses ASHS Press, Alexandria, VAJanick J 1999, 152-159.

38. Sunil N, Varaprasad KS, Sivaraj N, Suresh Kumar T, Abraham B, Prasad RBN: Assessing Jatropha curcas L. germplasm in-situ-A case study. Biomass and Bioenergy 2008, 32:198-202.

39. Sun QB, Li LF, Li Y, Wu GJ, Ge XJ: SSR and AFLP Markers Reveal Low Genetic Diversity in the Biofuel Plant Jatropha curcas in China. Crop Sci 2008, 48:1865-1871.

40. Linden Vander CG, Wouters DC, Mihalka V, Kochieva EZ, Smulders MJM, Vosman B: Efficient targeting of plant disease resistance loci using NBS profiling. Theor Appl Genet 2004, 109:384-393.

41. Doyle JJ, Doyle JL: A rapid DNA isolation procedure for small quantities of fresh leaf tissue. Phytochem Bull 1987, 19:11-15.

42. Zou ML, Ling P, Zhang Y, Wei ZS, Xia ZQ, Wang WQ: Mining EST derived SSR markers and use for genetic diversity evaluation in cassava (Manihot esculenta Crantz).

43. Mba REC, Stephenson P, Edwards K, Melzer S, Nkumbira J, Gullberg U, Apel K, Gale M, Tohme J, Fregene M: Simple sequence repeat (SSR) markers survey of the cassava (Manihot esculenta Crantz) genome: towards an SSR-based molecular genetic map of cassava. Theor Appl Genet 2001, 102:21-31.

44. Rohlf FJ, NTSYS-pc: numerical taxonomy system ver.2.1. Exeter Publishing Ltd., Setauket, New York 2002.

45. Yeh FC, Yang R, Boyle TJ, Ye Z, Xiyan JM: PopGene32, Microsoft Windowsbased Freeware for Population Genetic Analysis, Version 1.32. Molecular Biology and Biotechnology Centre, University of Alberta, Edmonton, Alberta, Canada 2000.

doi:10.1186/1756-0500-3-42

Cite this article as: Wen et al:: Development of EST-SSR and genomicSSR markers to assess genetic diversity in Jatropha Curcas L. BMC Research Notes 2010 3:42.

\section{Submit your next manuscript to BioMed Central and take full advantage of:}

- Convenient online submission

- Thorough peer review

- No space constraints or color figure charges

- Immediate publication on acceptance

- Inclusion in PubMed, CAS, Scopus and Google Scholar

- Research which is freely available for redistribution

Submit your manuscript at www.biomedcentral.com/submit
C Biomed Central 